\title{
TRANSFER IPTEK KELOMPOK MASYARAKAT HILIR (DOWNSTREAM) DI KELURAHAN KOMO LUAR MANADO
}

\author{
Wilmy E. Pelle ${ }^{1}$ dan Adnan S. Wantasen ${ }^{2}$ \\ Staf Pengajar pada Program Studi IImu Kelautan ${ }^{1}$ dan \\ Program Studi Manajemen Sumberdaya Perairan ${ }^{2}$, \\ Fakultas Perikanan dan IImu Kelautan. UNSRAT. Manado 95115.
}

\begin{abstract}
The district of Komo Luar is one of the downstream areas of River Tondano Based on some researches, performance of physic-chemical parameters show under of Indonesian Water Quality Guidelines e.g. dissolved oxygen, nitrate, phosphate, and e. colii. Knowledge and Technology Transferring has chosen in order to implement the soft approaches. Some programme has been done for example, training related to water quality and awareness campaign. We expected this programme coula be modify the way of thinking of people around the river.
\end{abstract}

Keywords: downstream community, water quality, soft approach

\section{PENDAHULUAN}

Secara alami daerah hilir (downstream) terposisikan sebagai suatu akhir dari aliran sungai sebelum sampai ke perairan laut. Selain air sebagai media utama, unsur-unsur fisika, kimia dan biologi turut serta dalam aliran dari suatu sistem sungai. Lebih dari itu, salah satu elemen yang tidak diinginkan pun bahkan kadangkala eksis seperti hadirnya polutan sebagai sumber pencemaran.

Kelurahan Komo Luar Kècamatan Wenang, Manado, merupakan Salah satu daerah downstream yang dialifi Daerah Aliran Sungai (DAS) Tondano. Penduduk yang bermukim tepat pada sempadan sungai umumnya bermata pencaharian sebagai nelayan, pedagang pasar dan buruh bangunan (BPS, 2008). Hanya sedikit yang berstatus sebagai pegawai negeri sipil dan swasta. Tingkat pendidikan terakhir umumnya SMP dan SMA, sebagian hanya lulus SD.

Berdasarkan hasil analisis secara fisika-kimia, performance dari Dissolved Oxygen (DO) dan Chemical Oxygen Demand (COD) tergolong dalam Klas 3 sesuai kajian PP. No.82 thn 2001 tentang pengelolaan kualitas air (Pelle, 2009). Demikian halnya dengan Phosphate. Berbeda dengan ammonia, selama periode sampling berlangsung hasil analisis menunjukan kondisi yang baik, namun dengan melihat data hasil dari BPLH (2006), kadar amonia pada sungai Tondano ini menunjukan nilai yang cukup tinggi. Perbedaan hasil ini dapat disebabkan oleh berbedanya kondisi alam saat sampling di lapangan. Pelle (2009) melakukan sampling selama musim hujan, jadi diasumsikan saat musim hujan ini terjadi pengenceran yang cukup tinggi oleh karena masuknya air hujan ke dalam air sungai. Jumlah e.colii mencapai 1000 bahkan lebih dari 2000/100 ml (Palandeng, 2010), dimana angka ini sudah melebihi ambang batas dari standar kualitas air di Indonesia. PP No. 82 thn 2001 merupakan suatu guidelines dalam pengklasifikasian kualitas air dengan peruntukannya. Kelas 1 diperuntukan sebagai sumber pengolahan air minum, yaitu kondisi kualitas air berperformance sangat baik. Kelas 2 untuk rekreasi, Kelas 3 untuk budidaya dan pertanian, sedangkan Kelas 4 tidak dianjurkan untuk penggunaan apapun selain navigasi, mengingat kualitas yang terlihat menunjukan kondisi yang buruk.

Menurut survey di lapangan serta hasil interview dengan masyarakat setempat (Pelle, 2009), masyarakat sekitar daerah ini sering memanfaatkan sungai Tondano untuk kebutuhan air sehari-hari seperti mandi, cuci manakala air yang didistribusikan oleh PT. Air Manado tidak mecukupi apalagi saat musim kemarau. Lebih jauh lagi, pembuatan sumur-sumur dekat sungai berpeluang terjadinya perembesan air su- 
ngai ke air tanah dan akan berdampak pada kesehatan lingkungan.

\section{Permasalahan Mitra}

Melihat kondisi masyarakat yang masih memanfaatkan Sungai Tondano sebagai sumber untuk keperluan air dalam rumah tangga, merefleksikan bahwa sebetulnya mereka belum memahami secara benar akan pentingnya kualitas air. Kurangnya kesadaran ini boleh jadi disebabkan oleh kurangnya atau tidak adanya informasi tentang kualitas air dalam kesehatan masyarakat dan lingkungan. Berdasarkan data dari Puskesmas di wilayah ini, penyakit dengan penderita terbanyak selama tahun 2008 adalah diare dan demam berdarah (Palandeng, 2010). Kedua jenis penyakit ini disebabkan oleh buruknya sistem pengelolaan air, dimana diare disebabkan oleh hadirnya bakteri e.coli dan deman berdarah disebabkan oleh buruknya sistem drainase yang mengakibatkan munculnya daerahdaerah genangan air.

Terlalu klasik untuk menanyakan siapa seharusnya yang bertanggung jawab dalam memberikan informasi penting ini, dengan melihat tingkat pendidikan masyarakat yang paling tinggi adalah SMP dan SMA. Tidak menyalahkan lagi pihak mana yang bersinergis dengan kebutuhan masyarakat, tetapi bagaimana kita bisa berkontribusi untuk mencari langkah-langkah solusi yang tepat untuk memecahkan permasalahan yang dihadapi masyarakats

\section{Tujuan Kegiatan}

Kegiatan pengabdian kepada masyarakat Kelurahan Komo Luar bertujuan untuk menerapkan rekomendasi hasil penelitian dafi beberapa peneliti yang telah dilakukan sebelumnya. Secara spesifik, sosialisasi dan pelatihan yang dilakukan diharapkan dapat menjawab tujuan khusus becikut ini:

1. Mendeskripsikan pemahaman masyarakat tentang pentingnya kesehatan lingkungan secara khusus dalam bidang air minum dan sanitasi.

2. Mendorong masyarakat selaku mitra kegiatan pengabdian dalam penyadaran lingkungan dan pentingnya kualias air.
3. Menerapkan metode soft approaches yang dinilai mampu mengubah pola pikir masyarakat dalam waktu yang relatif terbatas.

4. Melihat permasalahan yang berkenaan dengan sosial-ekonomi masyarakat setempat.

\section{METODE}

Kegiatan pengabdian dilakukan dengan menerapkan metode kualitátif yăng diawali dengan pengumpulan dáta sékunder. Selanjutnya implementasi kegrátan ditempuh dengan metode soft approaches seperti sosialisasi yang dilakukan dengan penyuluhan dan pelatihan.

Kelurahan Komo Luar adalah wilayah yang berada didalam Kecamatan Tikala Kota Manado, dimana bagian utara berbatasan dengán - Kélurahan Singkil dan Sungai Tondano, bagian selatan berbatasan dengân Kelurahan Komo Dalam, bagian timur berbatasan dengan Kelurahan Dendengân dan bagian barat berbatasan dengan Kompleks Pusat.

Model sosial-ekonomi masyarakat sebetulnya bersifat perkotaan modern. Hal 'ini ditandai dengan beragam usaha dan bisnis yang mendominasi pemukiman jalan utama. Namun, pemandangan yang kontras terlihat saat melintasi daerah sekitar sepadan Sungai Tondano, pemukiman yang cukup padat dengan areal lahan yang sangat terbatas. Masyarakat sempadan sungai ini umumnya bermata-pencaharian sebagai nelayan, buruh bangunan, pedagang dan sedikit yang berprofesi sebagai pegawai negeri sipil serta karyawan. Kelompok masyarakat inilah yang kemudian dipilih sebagai daerah percontohan atau mitra dari kegiatan pengabdian pada masyarakat. Dari segi pendidikan, umumnya berpendidikan tertinggi setara SMP dan SMA, dan sedikit yang berpendidikan $S_{1}$.

\section{HASIL DAN PEMBAHASAN}

\section{Peserta kegiatan}

Kegiatan penyuluhan diikuti oleh masyarakat yang bertempat tinggal di sepanjang atau dekat Sungai Tondano, yang selanjutnya dijadikan sebagai mitra dari kegiatan pengabdian kepada masyarakat. 
Jumlah mitra sekitar 50 orang dewasa dengan berbagai profesi. Penyuluhan dan pelatihan diikuti oleh 31 orang, dengan gender 27 orang laki-laki dan 14 orang perempuan. Domisili mitra berasal dari lingkungan 1, 2 dan 3 yang diikuti oleh $\mathrm{Ke}-$ pala-Kepala Lingkungan, BKM, organisasi Karang Taruna dan PKK. Dari segi pendidikan, peserta umumnya berpendidikan tertinggi setara SMP dan SMA dan sedikit yang berpendidikan S1.
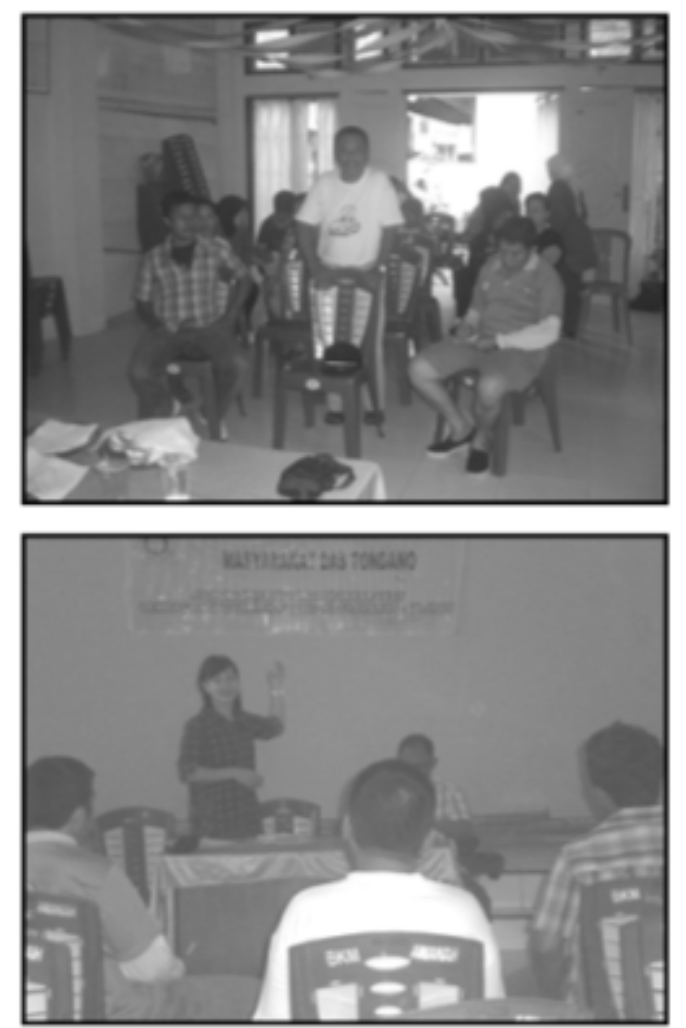

Gambar 1. Kegiatan SosialisaĹ dañ Pelatihan

\section{Realisasi kegiatan}

Berdasarkan latar balakang dan tujuan yang ditetapkan, maka serangkaian kegiatan telah dijaduralkan dari bulan Mei sampai Oktober 2010. Bulan pertama yakni bulan Mei, merupakan waktu untuk yang disediakan untuk memenuhi kelengkapan adminitras dengan pihak LPM UNSRAT yanğ diikuti dengan survey lokasi kegiatan dany penjadualan sosialisai yang dibicarakan bersama-sama dengan mitra, dalam hal ini pertemuan-pertemuan secara langsung maupun via telepon dilakukan dengan Lurah Kelurahan Komo Luar.

Setelah bebapa kali survei dilakukan, penetapan kegiatan sosialisasi akhirnya berhasil disetujui dan sedianya dilakukan pada minggu kedua bulan Juni 2010.
Sosialisasi dilakukan melalui penyuluhan tentang pentingnya kualitas air, sehingga persyaratan tentang standarisasi kualitas air berdasarkan PP No.82 Tahun 2004 telah diperkenalkan. Di dalam PP ini menjelaskan tentang persyaratan dalam pengelolaan badan air yang dapat bersumber dari air sungai, air tanah maupun danau dan dikelompokkan ke dalam kelas 1, 2, 3 dan 4 berdasarkan peruntukannnya. Kelas 1 adalah kondisi air yang dapat dimanfaatkan untuk air baku air minum, kelas 2 untuk rekreasi, budidaya ikan tawar, peternakan dan pertanaman. Kelas 3 untuk budidaya ikan air tawar, peternakan dan péngairan tanaman, sedangkan kelas 4 untuk mengairi pertanaman dan sebagainya sesuai persyaratan pemanfaatan air. Ringkasnya, kelas 1 merupakan air yang memiliki kualitas terbaik dengan uji parameter-parameter kualitas air secara fisika, kimia dan mikrobiologi, kemudian diikuti kelas 2 dan 3 . Kelas 4 merupakan kondisi kualitas yang paling barruk sehingga peruntukannya akan sangat terbătas (Anonimous, 2007).

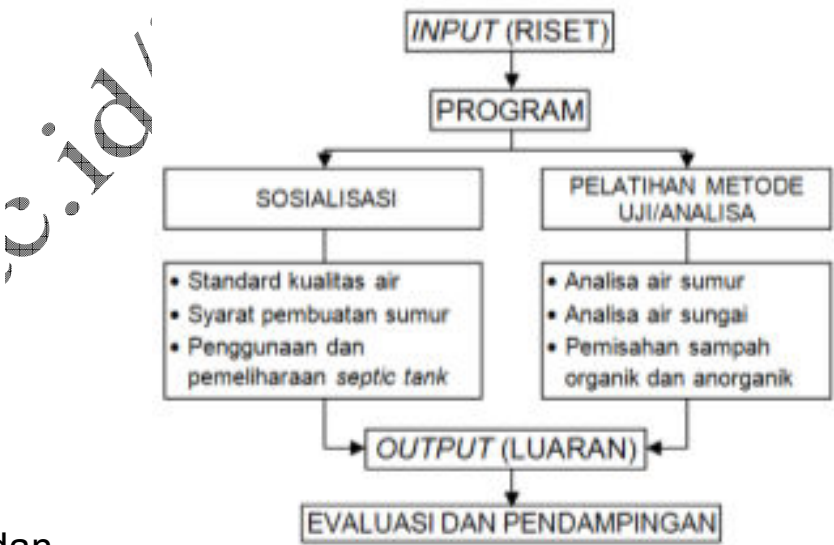

Gambar 2. Kerangka Kegiatan Pengabdian kepada Masyarakat

Masyarakat setempat memanfaatkan air yang umumnya bersumber dari air tanah disamping pemanfaatkan air yang bersumber dari perusahaan air yakni PDAM. Dari hasil wawancara dan pengamatan di lapangan, memperlihatkan suatu kondisi yang unik walaupun lumrah bagi mereka (masyarakat setempat), dimana pemanfaatan air sungai untuk mandi dan rekreasi anak-anak adalah salah satu alternatif yang tercepat.

Pemanfaatan sumur mendominasi eksploitasi sumber air, oleh sebab itu pengenalan tentang syarat-syarat lokasi yang 
akan dijadikan sumur gali diperkenalkan. Seperti jarak keliling sumur terhadap toilet/wc yang berseptic-tank dan jenis tanah, yang kelihatannya belum dipahami betul oleh masyarakat. Kemudian jenis septictank dan pemeliharaannya berhasil diperkenalkan kepada masyarakat.

Dari hasil diskusi dan wawancara, terdokumentasi bahwa masyarakat belum begitu memahami tentang beberapa topik yang dijelaskan dalam penyuluhan, dimana fakta memperlihatkan umumnya mereka membuat sumur gali tanpa memperhitungkan jarak dengan penggunaan lahan sekitarnya seperti septic-tank dan sistem drainase. Kemudian uji laboratorium untuk mengetahui apakah sumur yang akan dijadikan sumber air tidak dilakukan. Mereka hanya menilai terbatas pada kejernihan/kekeruhan air saja.

Respons masyarakat sangat baik, hal ini ditunnjukkan melaui keaktifan masyarakat untuk bertanya, meminta klarifikasi tentang pengetahuan yang ada, bahkan banyak yang menginginkan agar supaya program dan pendampingan terus dilakukan. Beberapa pertanyaan yang berkenaan yang berkenaan dengan kualitas air dan kesehatan lingkungan, dijawab sesuai proporsinya, tetapi teknis dan contoh-contoh dijelaskan pada sesi pelatihan.

Sesudah penyuluhan, kegiatan lanjutkan dengan pelatihan yang, diawali dengan pengenalan beberapa parameter kualitas air seperti suhu, salinitas, kekeruhan, untuk parameter fisik, Parameter kimia meliputi BOD, nitrat, fosfát, logam dan logam berat yang berbahaya. Selain itu pengenalan parameter mikrobiologi seperti $e$. coli, faecal dan total coliform. Pengenalan dilakukan secara sederhana dengan istilahistilah yang mudah dipahami. Pengenalan uji/analisa air baku pun diperkenalkan secara sederhana dan dengan istilah yang mudah dimengerti. Demikian halnya dengan penjelasan metode pemisahan sampah basah dan kering turut dilatihkan kepada masyarakat setempat.

Dari serangkaian kegiatan tersebut, nampak peran serta aktif dari mitra yang menunjukkan ketertarikan mereka terhadap isu-isu dan pelatihan yang disampaikan. Bahkan dengan keterbatasan waktu yang tersedia, masyarakat memanfaatkan de- ngan menanyakan dan mengkonfirmasikan hal-hal termasuk pengalaman yang dihadapi berkaitan dengan isu kualitas air dan sistem sanitasi lingkungan.

\section{Luaran (Output)}

Luaran yang awalnya diharapkan dari aksi ini adalah terciptanya suatu kelompok masyarakat kecil yang memahami pentingnya kualitas air dibarengi dengan pengetahuan yang memadai. Setelah memahami, diharapkan mereka sadar sepenuhnya untuk mengaplikasikan dalan pola hidup sehari-hari.

Tercapainya salah satu MDGs (Millenium Develpment Goals) yaitu masyarakat yang bersih sanitasi dan lingkungan. Hal ini dapat diwujudpyatakan dengan konsumsi air yang bersih dan higienis bebas dari polutan, baik tuntuk minum, mandi, cuci dan rekreasi.jDengan demikian peluang munculnya penyakit seperti diare dan demam berdarah sangat kecil atau bahkan tidak ada.

- Selain target di atas, pada akhir kegiatan diupayakan untuk dicapai hal-hal xang jelas dan dapat diukur sebagai berikut:

Diadakan sertifikat bagi mitra sebagai indikasi terlaksananya program pentransferan IPTEK. Sertifikat akan diberikan bagi semua anggota yang tergabung dalam kelompok masyarakat hilir (downstream) di Kelurahan Komo Luar. Lebih jelas lagi sertifikat hanya akan diberikan bagi anggota yang dinilai aktif mengikuti serangkaian kegiatan yang telah dilakukan.

- Penciptaan dan penerapan metode analisis air dan pengelolaan sampah. Secara sederhana diharapkan metode ini dapat terus diimplementasikan oleh masyarakat dan berlangsung secara kontinyu.

Jika kelompok masyarakat kecil ini berhasil merubah kondisi lingkungan diakibatkan oleh berubahnya pola pikir dan gaya hidup mereka, maka kelompok ini bisa dijadikan suatu kelompok percontohan bagi kelompok masyarakat yang lain.

\section{Pemantauan dan Evaluasi}

Setelah realisasi kegiatan, Tim melakukan evaluasi dan pemantauan di la- 


\section{Transfer Iptek pada Masyarakat}

pangan untuk melihat sejauh mana keberlanjutan dari kegiatan di bulan Juni 2010. Pemantauan dilakukan minimal sekali dalam sebulan sejak bulan Juli hingga Oktober 2010, dengan cara peninjauan langsung di lokasi dan wawancara dengan masyarakat. Dari pemantauan yang dilakukan, terlihat bahwa perilaku masyarakat mengalami perubahan dari segi kesadaran tentang kualitas air dan sanitasi lingkungan. Peningkatan signifikan terlihat pada bulan Juli dan Agustus, namun mengalami penurunan pada bulan September dan Oktober. Tren ini kemungkinan disebabkan oleh keterbatasan pola pikir atau oleh keterbatasan kondisi sosial budaya yang masih melekat di masyarakat. Sehingga solusi yang terumuskan dapat ditempuh dengan revitalisasi dari sosialisasi yang telah dilaksanakan.

Solusi yang ditempuh melalui realisasi kegiatan dinilai memiliki keberhasilan meskipun terdapat keterbatasan dalam penanganan masalah mitra. Kegiatan berupa sosialisasi (penyuluhan) dan pelatihan uji/analisis sumber air dipandang efektif bagi masyarakat setempat. Namun oleh karena keterbatasan waktu dan biaya, kegiatan tersebut tidak dapat terealisasi untuk tahap lanjutan. Selain itu, salah satu indikator lingkungan seperti pengelolaan sampab belum menyentuh seluruh lapisan masyarakat. Jika dilihat dari data peserta p̌enyuluhan dan pelatihan, umumnya diikuti oleh orang tua. Oleh sebab itu, keberlajutan kegiatan diupayakan lebih bersifat komperhensif, artinya seluruh efemen masyarakat remaja dan dewasa dapat terlibat didalamnya.

\section{KESIMPULAN}

Transfer ilmu pengetahuan dan teknologi telah diimplementasikan sesuai waktu yang dialokasikan. Kegiatan ini mendapat respons baik dari masyarakat selaku mitra bahkan ada keinginan untuk melanjutkan (follow-up) segenap penyuluhan dan pelatihan yang telah disosialisasikan. Untuk itu akan diupayakan sumber dana (donor) apakah dari pemerintah atau kegiatan- kegiatan pengabdian masyarakat lainnya untuk dapat memfasilitasi kegiatan yang telah dirintis. Dari evaluasi dan pematauan di lapangan, kegiatan penyuluhan dan pelatihan berhasil menyentuh berbagai lemen mitra, yang ditandai dengan kehadiran beragam jabatan dan profesi di Kelurahan Komo Luar, seperti Kepala Lingkungan, anggota, BKM, organisasi Karang Taruna dan kelompok PKK. Selain itu gender dinilai telah mewakili peserta dengan kehadiran beberapa peserta berasal dari kaum perempuan.

Metode soft approaches telah berhasil menyentuh dan merubah pola pikir masyarakat dimana munculnya keinginankeinginan untuk memperbaiki kondisi yang kurang memadai sepertil kondisi yang nampak saat ini. ANamun yang menjadi keterbatasan Tim dan mitra itu sendiri adalah bagaimana mengubah kondisi secara komperhensif, apakah perlu dilakukan penyediaan toilet komunal yang dapat dimanfalkan secara bersama-sama. Usul penciptaan teknologi baru untuk masyarakat perlu untuk dipikirkan dan segera direalisasikan, namun yang menjadi kendala adalah suplai dana yang belum ada sampai sejauh ini.

\section{DAFTAR PUSTAKA}

Anonimous, 2008. BPS (Biro Pusat Statistik) Manado. Manado Dalam Angka. Indonesia.

Anonimous, 2006. BPLH (Badan Pengelolaan Lingkungan Hidup) Propinsi Sulawesi Utara. Laporan Akhir dalam Pemantauan Sungai Tondano. Manado, Indonesia.

Palandeng H.M., 2010. Microbial Risk Analysis at Manado Community. Thesis in Water Quality Management. UNESCO-IHE Institute for Water Education. Delft, The Netherlands.

Pelle, W.E., 2009. Pollution Sources and Source Protection Measures in Tondano River Basin Territory, North Sulawesi, Indonesia. Thesis in Water Quality Management. UNESCO-IHE Institute for Water Education. Delft, The Netherlands. 